\title{
Correction to: JNK-NQO1 axis drives TAp73-mediated tumor suppression upon oxidative and proteasomal stress
}

A. Kostecka', A. Sznarkowska', K. Meller' ${ }^{1}$, P. Acedo², Y. Shi, H. A. Mohammad Sakil², A. Kawiak', M. Lion³ , A. Królicka', M. Wilhelm², A. Inga ${ }^{3}$ and J. Zawacka-Pankau, ${ }^{1,2}$

Correction to: Cell Death Dis. 5, e1484 (2014); https:// doi.org/10.1038/cddis.2014.408; published online 23 October 2014.

Following publication of their article JNK-NQO1 axis drives TAp73-mediated tumor suppression upon oxidative and proteasomal stress. Cell Death Dis. 2014, 5:e1484, the authors noted a mistake in Fig. 2b, in that, the wells of the crystal violet plates showing growth inhibition induced by withaferin A in HCT $116^{\text {TP53-/- }}$ cells were erroneously duplicated for 1 and $2.5 \mu \mathrm{M}$ WA. The correct wells for $2.5 \mu \mathrm{M}$ WA are now included in new Fig. $2 \mathrm{~b}$.

The authors apologise for any inconvenience caused.

Correspondence: J. Zawacka-Pankau (joanna.zawacka-pankau@ki.se)

'Department of Biotechnology, Intercollegiate Faculty of Biotechnology,

University of Gdansk and Medical University of Gdansk, Gdansk, Poland

²Department of Microbiology, Tumor and Cell Biology, Karolinska Institutet,

Stockholm, Sweden

${ }^{3}$ Centre for Integrative Biology, CIBIO, University of Trento, Mattarello, Italy

(c) The Author(s) 2018

(c) Open Access This article is licensed under a Creative Commons Attribution 4.0 International License, which permits use, sharing, adaptation, distribution and reproduction BY in any medium or format, as long as you give appropriate credit to the original author(s) and the source, provide a link to the Creative Commons license, and indicate if changes were made. The images or other third party material in this article are included in the article's Creative Commons license, unless indicated otherwise in a credit line to the material. If material is not included in the article's Creative Commons license and your intended use is not permitted by statutory regulation or exceeds the permitted use, you will need to obtain permission directly from the copyright holder. To view a copy of this license, visit http://creativecommons.org/licenses/by/4.0/. 


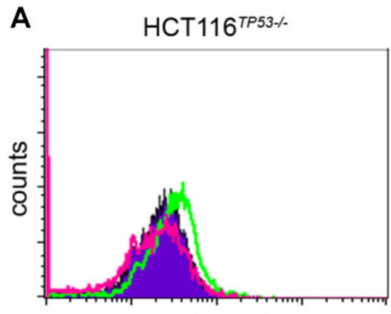

FL1-H

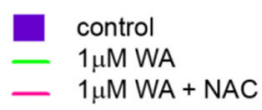

C

HCT116 ${ }^{\text {TP53-1 }}$

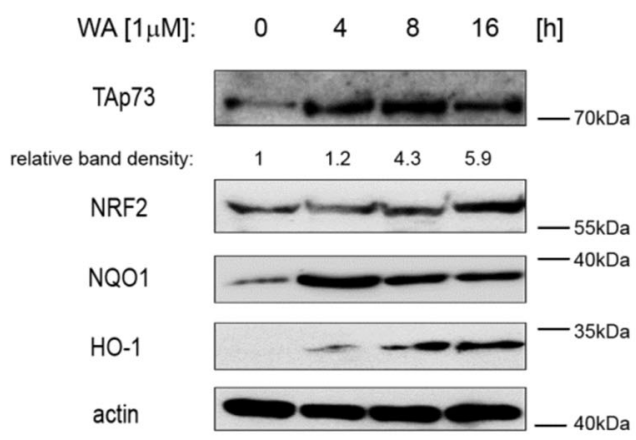

E

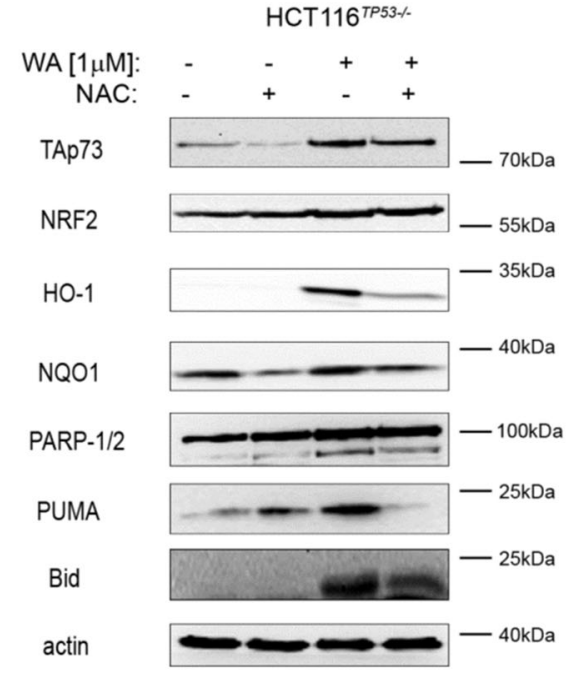

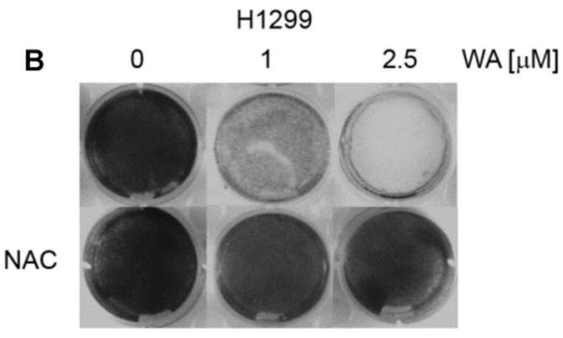

HCT116 ${ }^{\text {TP53- }}$

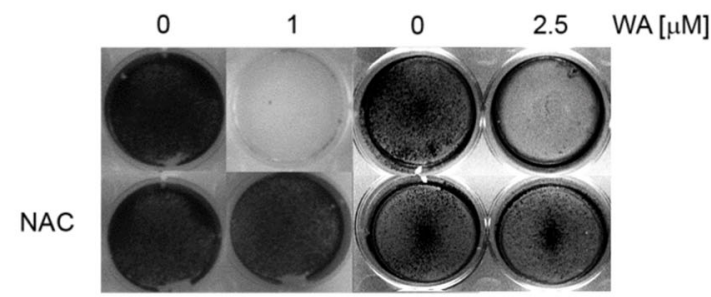

D $\quad$ HCT116 1 TP5\%

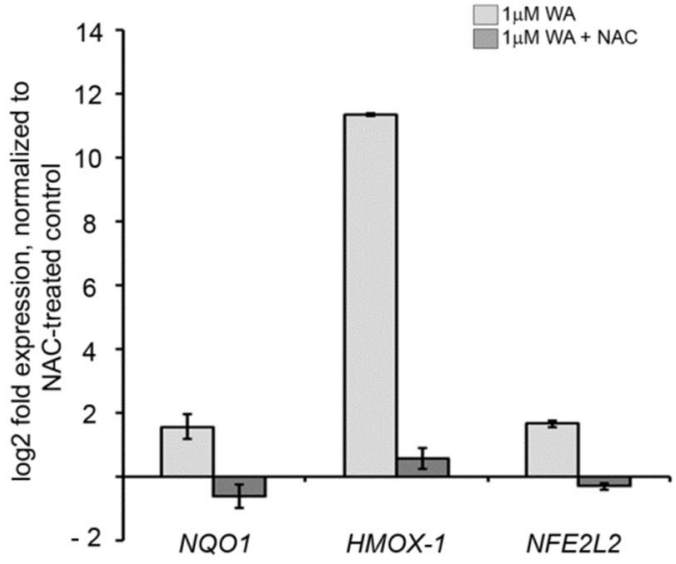

F

HCT116 ${ }^{\text {TP53- }}$

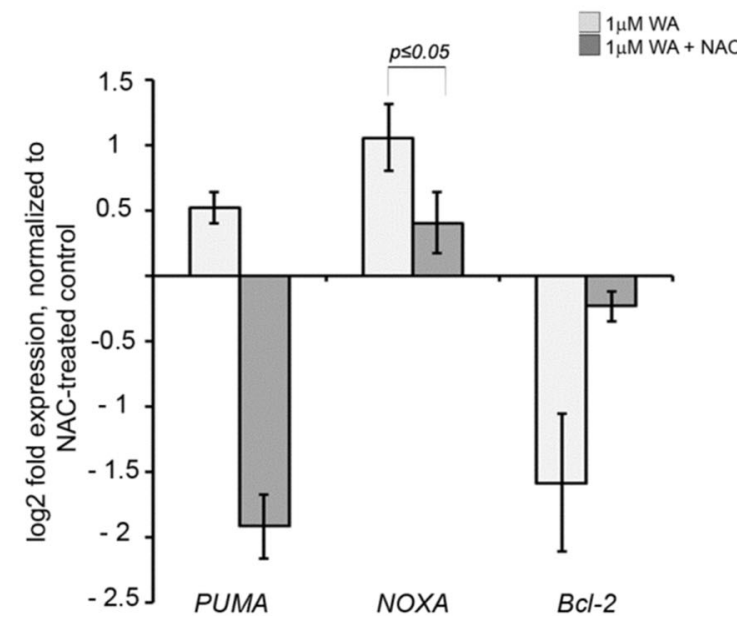

Fig. 2 